\title{
Effect of artemisinin alone and artemisinin with folic acid on the lipid profile of rat
}

\author{
Aniefiok S. UDOBRE ${ }^{1}$, Olorunfemi A. ESEYIN ${ }^{1 *}$, Etim IWEH ${ }^{1}$ and \\ Uwemedimo $\mathrm{UMOH}^{2}$ \\ ${ }^{1}$ Department of Pharmaceutical and Medicinal Chemistry, \\ ${ }^{2}$ Department of Pharmacognosy and Natural Medicine, \\ Faculty of Pharmacy, University of Uyo, Uyo Akwa Ibom State, Nigeria. \\ *Corresponding author; E-mail: femieseyin2@yahoo.co.uk; Tel: +234806516478
}

\begin{abstract}
Studies were carried out on the effect of artemisinin alone and with folic acid on total cholesterol, triacylglycerol and lipoprotein fractions in the serum of male Wistar rats. Different groups of rats $(n=8)$ were orally given $0.75,1.50,3.00$ and $6.00 \mathrm{mg} / \mathrm{kg}$ body weight of artemisinin, respectively. Each of these groups also was orally administered $1.50 \mathrm{mg} / \mathrm{kg}$ of folic acid concurrently. Analyses of results showed a significant $(\mathrm{P}<0.05)$ increase in the level of total cholesterol in the serum from $2.479 \pm 0.25$ to $3.964 \pm 0.21 \mathrm{mmole} / \mathrm{L}$. In contrast, triacylglycerol level decreased simultaneously from $0.75 \pm 0.11$ to $0.414 \pm 0.04 \mathrm{mmole} / \mathrm{L}$. The ratio of the Low Density Lipoprotein to High Density Lipoprotein reversed from 1:2 to 2:1. These results suggest that folic acid offers complete relief to lipid disorders associated with low doses of artemisinin but partial relief to the same disorder caused by high doses of the drug.

(c) 2010 International Formulae Group. All rights reserved.
\end{abstract}

Keywords: Artemisinin, cholesterol, malaria, LDL, HDL, triacylglycerol.

\section{INTRODUCTION}

Malaria is caused by Plasmodium species. Despite increasing research and control efforts, malaria still remains a major health problem. It is the most important vector borne disease (Curtis, 1993). Between 300 and 500 million people experience clinical episodes and 1.4 to 2.6 million deaths occur yearly with about $90 \%$ mortality associated with tropical Africa and south-east Asia where the disease is very prevalent (WHO, 1993; Coker et al., 2001). These regions of the world are characterized by optimum conditions of temperature, heavy rainfall and dense vegetation which promote the survival of the Plasmodium species (Curtis, 1993).

Chloroquine is the cheapest and the most widely available first line drug. The spread and intensity of resistance by the malarial parasite to chloroquine and other antimalarials such as mefloquine, including combination drugs (Molta et al., 1994; Olliaro and Trigg, 1995; Sowunmi et al., 1996) necessitated the search for new drugs. This effort led to the choice of Artesunate which is obtained from the plant Artemisia annua (Woedenbag et al., 1994) and from which the antimalaria principle (Artemisinin) was discovered in 1971 (Liy and $\mathrm{Wu}, 1998)$. 
Artemisinin works by destroying the cell membrane of the parasite, slowing down protein synthesis, disorganizing the ribosome, dilating the nuclear envelope and disintegrating the food vacuoles. In the mosquito life cycle, it inhibits the development of the trophozoites, kills the schizont of the parasite and prevents progression of the disease (Meshnik, 1996). It is considered as an effective alternative drug for falciparum malaria (Karbwang et al., 1994; Baradell et al., 1995).

Earlier work by Udobre et al. (2009) showed that folic acid alleviated the effect of artemisinin on some enzyme levels when they were co-administered. This study was undertaken to determine the effect of artemisinin on lipid profile and whether folic acid could reverse this effect.

\section{MATERIALS AND METHODS}

\section{Animals}

Adult Wistar rats weighing between 150 and $180 \mathrm{~g}$ were used. They were fed with grower's marsh (Vital Feeds Limited, Lagos) and water ad libitum and kept in the Animal House of the Faculty of Pharmacy, University of Uyo, under standard laboratory conditions.

\section{Drugs/Chemicals}

Artemisinin (manufactured by Mekopharm Chemical company, Vietnam but purchased in Uyo), Folic Acid (Unique Pharmaceuticals, Lagos, Nigeria) and freshly prepared $0.9 \% \mathrm{w} / \mathrm{v}$ normal saline.

\section{Administration of drugs/chemical on the animals}

Seventy- two overnight fasted rats were divided into nine equal groups (each containing 8 rats). The drugs were administered orally to the rats once daily for five days as shown below (Udobre et al., 2009):

Group A received $0.75 \mathrm{mg} / \mathrm{kg}$ artemisinin only.

Group B received $0.75 \mathrm{mg} / \mathrm{kg}$ artemisinin and $1.50 \mathrm{mg} / \mathrm{kg}$ folic acid.

Group C received $1.50 \mathrm{mg} / \mathrm{kg}$ artemisinin only Group D received $1.50 \mathrm{mg} / \mathrm{kg}$ artemisinin and $1.50 \mathrm{mg} / \mathrm{kg}$ folic acid
Group E received $3.00 \mathrm{mg} / \mathrm{kg}$ artemisinin only.

Group F received $3.00 \mathrm{mg} / \mathrm{kg}$ artemisinin and $1.50 \mathrm{mg} / \mathrm{kg}$ folic acid.

Group $\mathrm{G}$ received $6.00 \mathrm{mg} / \mathrm{kg}$ artemisinin only.

Group $\mathrm{H}$ received $6.00 \mathrm{mg} / \mathrm{kg}$ artemisinin and $1.50 \mathrm{mg} / \mathrm{kg}$ folic acid.

Group I received saline water only (control).

\section{Collection of blood and preparation of serum}

Overnight fasted rats were sacrificed on the $6^{\text {th }}$ day and blood collected by cardiac puncture. The serum was prepared from clotted blood by gently decanting the liquid part from the cells into iron-free centrifuge tubes and the tubes were spun at 10,000 rpm for 5 minutes in a centrifuge (MSE England). The serum was then decanted into another set of clean tubes and stored at $10{ }^{\circ} \mathrm{C}$ for a period not exceeding 24 hours (Udobre et al., 2009).

\section{Estimation of total cholesterol and HDL- cholesterol}

The serum samples obtained from the blood of the sacrificed animals were analysed. Total cholesterol (TC) and HDL-cholesterol were estimated using cholesterol enzymatic colometric CHOD-PAD method (Richmond, 1973). The absorbance of the test solution was measured using a UV-Vis NIR Spectrophometer, U.S.A, Model 6/20A, at a wavelength of $500 \mathrm{~nm}$ and a temperature of $37{ }^{0} \mathrm{C}$. Triacylglycerol (TG) in the serum sample was estimated by GPO-PAP method (Trinder, 1996) at $540 \mathrm{~nm}$ and $37{ }^{\circ} \mathrm{C}$.

Very Low Density Lipoprotein (VLDL)and Low Density Lipoprotein (LDL)Cholesterol were estimated as follows ( Friedelwald et al., 1972): VLDL $=\mathrm{TG} \div 2.2$ $\mathrm{LDL}=\mathrm{TC}-(\mathrm{HDL}+\mathrm{VLDL})$.

\section{Statistical analysis}

The data obtained were expressed as the mean \pm standard deviation. Student's $t$ - test was used for the analysis of the level of significance and $\mathrm{P}<0.05$ was taken to be statistically significant. 
Table 1: The effect of oral administration of daily dose of artemisinin (Artesunate), and artemisinin with folic acid on serum lipid profile.

\begin{tabular}{|c|c|c|c|c|c|c|c|}
\hline Groups & Treatment (mg/kg body wt.) & $\begin{array}{c}\text { Serum TC } \\
(\mathrm{mmol} / \mathrm{L})\end{array}$ & $\begin{array}{c}\text { Serum TG } \\
(\mathrm{mmol} / \mathrm{L})\end{array}$ & $\begin{array}{l}\text { Serum VLDL } \\
\quad(\mathrm{mmol} / \mathrm{L})\end{array}$ & $\begin{array}{l}\text { Serum HDL } \\
(\mathrm{mmol} / \mathrm{L})\end{array}$ & $\begin{array}{l}\text { Serum LDL } \\
(\mathrm{mmol} / \mathrm{L})\end{array}$ & $\begin{array}{c}\text { Serum } \\
\text { HDL } \\
\text { Ratio }\end{array}$ \\
\hline A & $0.750 \mathrm{mg}$. ART & $3.148 \pm 0.13^{*}$ & $0.732 \pm 0.11 *$ & 0.332 & $1.404 \pm 0.13$ & 1.412 & $1: 1$ \\
\hline B & $0.750 \mathrm{mg}$. ART. $+1.00 \mathrm{mg}$ FA & $2.500 \pm 0.11 *$ & $0.733 \pm 0.31 *$ & 0.335 & $0.397 \pm 0.56$ & 0.770 & $1: 2$ \\
\hline $\mathrm{C}$ & $1.500 \mathrm{mg}$. ART & $3.461 \pm 0.09 *$ & $0.508 \pm 0.33 *$ & 0.231 & $1.369 \pm 0.31$ & $1.848 *$ & $1: 1$ \\
\hline $\mathrm{D}$ & $1.500 \mathrm{mg}$. ART.+1.500mg FA & $2.668 \pm 0.07 *$ & $0.596+0.14 *$ & 0.271 & $1.382+0.25$ & $1.015 *$ & $1: 1$ \\
\hline $\mathrm{E}$ & 3.000mg. ART & $3.648 \pm 0.08 *$ & $0.473 \pm 0.10 *$ & 0.215 & $1.349 \pm 0.35$ & $2.084 *$ & $2: 1 *$ \\
\hline $\mathrm{F}$ & $3.000 \mathrm{mg}$. ART $+1.500 \mathrm{mg}$ FA & $2.874 \pm 0.12 *$ & $0.525 \pm 0.13 *$ & 0.239 & $1.365 \pm 0.10$ & $1.210 *$ & $1: 1$ \\
\hline G & $6.000 \mathrm{mg}$. ART & $3.964 \pm 0.21 *$ & $0.414 \pm 0.04 *$ & 0.188 & $1.334 \pm 0.16$ & $2.439 *$ & $2: 1 *$ \\
\hline $\mathrm{H}$ & $6.000 \mathrm{mg}$. ART. $+1.500 \mathrm{mg}$ FA & $2.960 \pm 0.15 *$ & $0.454 \pm 0.09 *$ & 0.206 & $1.399 \pm 0.022$ & $1.355^{*}$ & $1: 1$ \\
\hline I & Normal Saline (control) & $2.479 \pm 0.25$ & $0.725 \pm 0.11$ & 0.330 & $0.406 \pm 0.05$ & 0.743 & $1: 2$ \\
\hline
\end{tabular}

FA: stands for folic acid; ART: artemisinin; TC: total cholesterol; TG: triglycerides; VLDL: very low density lipoproteins; HDL: high density lipoproteins; LDL: low density lipoproteins. The results are expressed as mean + S.D. $\quad *$ Statistical significance $(\mathrm{P}<0.05)$. 


\section{RESULTS AND DISCUSSION \\ Total cholesterol}

All the doses of artemisinin increased the concentration of total cholesterol in a dose dependent manner. Concomitant administration of artemisinin with folic acid mitigated this effect but did not bring the concentration of total cholesterol to the control level of 2.479 (Table 1).

\section{Triglycerides}

$1.5,3.0$ and $6.0 \mathrm{mg} / \mathrm{kg}$ of artemisinin significantly reduced the concentration of triglycerides from 0.725 to $0.508,0.473$ and $0.414 \mathrm{mmole} / \mathrm{L}$, respectively. But 0.750 $\mathrm{mg} / \mathrm{kg}$ artemisinin did not affect the concentration of triglycerides. Concurrent administration of artemisinin and $1.50 \mathrm{mg} / \mathrm{kg}$ folic acid did not affect the concentration of triglycerides at any of the dose levels of artemisinin (Table 1).

\section{LDL-cholesterol}

Administration of artemisinin alone increased the concentration of LDL in a dose dependent manner. This increase was reversed by folic acid. At a low dose $(0.75 \mathrm{mg} / \mathrm{kg})$ of artemisinin, folic acid reversed the elevation of LDL to control level.

\section{HDL- cholesterol}

Only the low dose of artemisinin $(0.75$ $\mathrm{mg} / \mathrm{kg}$ ) elevated the concentration of HDL. This elevation was reversed by folic acid to control level.

\section{VLDL-cholesterol}

Concentration of VLDL was significantly reduced only at a high dose of artemisinin $(6.00 \mathrm{mg} / \mathrm{kg})$. Low doses of artemisinin $(0.75$ and $1.50 \mathrm{mg} / \mathrm{kg})$ did not alter LDL/HDL ratio, but high doses of artemisinin $(3.00$ and $6.00 \mathrm{mg} / \mathrm{kg}$ ) reversed the ratio. This reversal was not observed when folic acid was co-administered with artemisinin (Table 1).

Hypercholesterolemia is a risk factor for cardiovascular diseases such as atherosclerosis and myocardial infarction, which is a common cause of mortality and morbidity. Blood levels of LDL- and HDLcholesterol are strong predictors of cardiovascular disease. High levels of cholesterol, particularly LDL-cholesterol, are mainly responsible for hypercholesterolemia. HDL-cholesterol is known to have antiatherogenic properties, while LDL-cholesterol constitute the primary carriers of plasma cholesterol which build up in the walls of the arteries, thereby causing atherosclerosis (Rang et al., 1995). Patients with arterial disease can have elevated VLDL or LDL or both (Murray, 1990). It can be deduced that the dose level of $6.00 \mathrm{mg} / \mathrm{kg}$ of artemisinin may have induced arterial disease in the rats under study. This is supported by the elevated values of TC, VLDL and LDL (Table 1).

The results of this study indicated that the administration of high dose $6.00 \mathrm{mg} / \mathrm{kg}$ of artemisinin to Wistar rats caused a significant $(\mathrm{P}<0.05)$ increase in total cholesterol from 2.479 to $3.964 \mathrm{mmole} / \mathrm{L}$ and a simultaneous decrease in triacylglycerol from 0.725 to $0.414 \mathrm{mmole} / \mathrm{L}$ (Table 1). There was also an increase in Low Density Lipoprotein (LDL) from 0.749 to $2.439 \mathrm{mmole} / \mathrm{L}$ and a simultaneous decrease in High Density Lipoprotein (HDL) from 1.406 to 1.334 mmole/L (Table 1).

Also the decrease in HDL may have caused a reduction in the rate of transportation of free cholesterol and cholesterylester from tissues to the liver where it is converted to bile acid (Murray, 1990; George, 2005).

Body cells extract cholesterol from the blood by means of receptors on their surfaces. These receptors bind with the LDL particles (and their attached cholesterol) and draw them from the blood into the cell. When more LDL particles are captured by the receptors of the body cells, the formation of more receptors on that cell's surface is inhibited, thus lowering its future intake of cholesterol. Fewer receptors on the body cells means that less cholesterol is ingested by the cells and that more remains in the blood stream, thus increasing the risk of cholesterol (LDL) accumulating in the internal walls of the blood 
vessels (Encyclopedia Britannica, 2010). This is a possible explanation for the reversal of the LDL: HDL ratio from 1:2 to $2: 1$. This implies that the dose level of $6.00 \mathrm{mg} / \mathrm{kg}$ body weight artemisinin may have caused accumulation of LDL on the receptors of the body cells thus inhibiting the formation of more body cell receptors by feed back mechanism.

The results in Table 1 also indicated that folic acid gave a complete relief to the lipid disorder associated with lower dose of artemisinin, but a partial relief to the same disorder associated with higher doses of the drug. This result is in tandem with the findings of Udobre et al. (2009) that folic acid offered complete relief to metabolic disorders at low dose while the relief was partial at high concentrations.

Adebayo et al. (2010) reported that artesunate reduced total cholesterol and HDLcholesterol concentration in serum, amodiaquine on the other hand reduced serum total cholesterol while reducing serum LDLcholesterol. Co -administration of artesunate and amodiaquine reduced total cholesterol and HDL- cholesterol and atherogenic index. Similarly, Obianime et al. (2009) also reported that total cholesterol was significantly reduced by co-administration if artesunate and amodiaquine. The result of the present study was the reverse of these reports.

The result of this study indicates that administration of high dose $(6.0 \mathrm{mg} / \mathrm{kg})$ of artemisinin to male Wistar rats caused a significant $(\mathrm{P}<0.05)$ increase in total cholesterol, a simultaneous decrease in triacylglycerol in the serum and a reversal of the LDL: HDL ratio from 1:2 to $2: 1$. Coadministration of the drug with folic acid is recommended to alleviate these effects.

\section{REFERENCES}

Adebayo JO, Igunnu A, Arise RO, Malomo SO. 2010. Effects of co- administration of artesunate and amodiaquine on some cardiovascular disease indices in rats. Food and Chem Toxicol. (in press).
Alvin AS, Eichelberger CB, Jones R, Whorton CM. 1998. Textbook on Adverse Drug Reaction. Macmillan; 130 - 136.

Baradell LB, Fitton A. 1995. Artesunate-A review of its pharmacological and therapeutic efficacy in the treatment of malaria. Drug, 50(4): $714-241$.

Coker HAD, Chukwuani CM, Ifudu ND, Aina BA. 2001. The Malaria Scourge: concept in disease management The Nigerian Journal of Pharmacy, 32: 19-48.

Curtis CF. 1993. Workshop on Bednets at the International congress of Tropical Medicine. Journal of Zoology, 2: 63 - 68.

Encyclopaedia Britainica. 2010. Lipoprotein. Encyclopaedia Britainica Student and Home Edition.

Friedewald WT, Levy RI, Fredrickson DS. 1972. Estimation of the concentration of LDL cholesterol in plasma, without use of the preparative ultra- centrifuge. Clin Chem.,; 18: 499-502.

George D, Pamplona, R. 2005. Encyclopedia of foods and their healing power. Education and Health Library. A Guide to Food Science and diet therapy. Vol 2; p. 83.

Karbwang J, Na-Bangchan K. 1994. Comparison of Oral Artesunate and Quinine plus tetracycline in acute uncomplicated falciparum Malaria. W. $H$. O., 72: $233-238$.

Liy W. 1998. How Chinese Scientists discovered Qinghaosu (Artemisinin) and its Derivatives. What are the future prospects? Medicine in the Tropics, 583: 9- 12 .

Meshnik SR, Taylor TE, Kamchong PS. 1996. Artemisinin and Antimalaria Endoperoxides: From Herbal remedy to target Chemotherapy. Microbiology, 60: $301-315$.

Molta NB, Daniel HI, Oguche SO, Watila IM. 1993. Malaria treatment failures in North Eastern Nigeria. Res. J. Sc., 1: 102110.

Murray RK, Mayes PA, Granner DH, Rodwell VW. 1990: Harper's Biochemistry (22nd edn). Prentice-Hall, USA; 249. 
Obianime AW, Aprioku JS. 2009. Comparative study of artesunate, ACTs and their combinants on the biochemical parameters of male guinea pigs. Afr. J. Biotech., 8(19): 5059-5065.

Olliaro PL, Trig PI. 1995. Status of Malaria drugs under development. WHO Bull. OMS. 73: 565 - 571 .

Rang AP, Dale MM, Ritter JM. 1995. Pharmacology (3rd edn). Churchill Livingstone: New York; 409.

Richmond W. 1973. Cholesterol enzymatic colorimetiric test (CHOD-PAP) for estimation of total and HDL cholesterol in serum. Clinical Chemist, 19: 13501356.

Sowunmi A, Odetola AMJ, Ilesanmi AO, Salako LA. 1996. Open comparison of Artemether and Mefloquine in uncomplicated Plasmodium falciparum hyperparasitemia in children. Annal. Trop. Paed., 16: 5-9.

Trinder P. 1969. Triglycerides estimation in serum. Annals of clinical Biochemistry, 6: $26-27$.

Udobre A, Edoho JE, Eseyin OA, Etim I. 2009. Effect of Artemisinin with Folic Acid on the Activities of Aspartate Amino Transferase, Alanine Amino Transferase and Alkaline Phosphatase in Rat. Asian J. Biochem., 4(2): 55-59.

Woedenbag HJ, Pras N, Uden W. 1994. progress in the research of Artemisinin related antimalarials: An update. Pharmaceutical World Science.

WHO. 1993. World Malaria Situation in 1991. Weekly Epidemiol. Rec., 68: 245 - 252. 